\title{
CHANGES IN THE OVARIAN FOLLICLE POPULATION OF MICE AGED 16 TO 20 DAYS
}

\author{
JOYCE KENT \\ United Birmingham Hospitals, Department of Clinical Endocrinology \\ Birmingham and Midland Hospital for Women, Birmingham B11 $4 H L$
}

(Received 19th May 1972, accepted 12th Fune 1972)

A number of authors (Brambell, 1927; Engle, 1931; Barraclough, 1955; Ben-Or, 1963; Peters, 1969; Byskov, Pedersen \& Peters, 1970; Stegner \& Onken, 1971) have described various aspects of the normal development of infantile and juvenile mouse ovaries. Pedersen $(1969,1970)$ examined the growth rate of mouse ovarian follicles of various sizes and the size distribution of the follicle population at 7, 14, 21, 28 and 35 days after birth. The present work is concerned with the changes between the ages of 16 and 20 days in the population of mouse ovarian follicles that have at least three layers of granulosa cells.

Foster litters of ten female CFW mice (nine sub-lines of the outbred CFW strain were obtained from the M.R.C. Laboratory Animals Centre, Carshalton, Surrey in 1966 and have since been systematically crossbred to maintain heterozygosity) were set up on the day of birth. Two mice from each of two such litters were killed 16,17, 18, 19 and 20 days after birth and their ovaries were fixed in Bouin's aqueous fixative. As these mice were removed from the cages, they were replaced with males of the same age to maintain a constant litter size. The ovaries were serially sectioned and stained with Weigert's haematoxylin and eosin. Each section was examined and all follicles with three or more layers of granulosa cells were recorded. The mean diameters of those with four or more layers were also determined. The three-layered follicles corresponded roughly to Type $5 \mathrm{a}$, the four- and five-layered follicles to Type $5 \mathrm{~b}$ and those with more than five layers to Type 6 of Pedersen \& Peters (1968).

Table 1 and Text-fig. 1 summarize the results. The Text-figure includes, for comparison, data for 15-day-old mice obtained in a separate experiment (Ryle, 1971). The number of follicles with three or more layers increased steadily up to Day 18 but remained constant thereafter. The mean diameters of four- and five-layered follicles did not change with age. Considerable recruitment into these classes occurred between 17 and 20 days. The mean follicle size distribution was similar at 17 and 18 days but the variation between individual ovaries was greater at 17 days than at any other age. For example, the standard error of the mean number of follicles per ovary in Columns 2 and 3 (Table 1) was maximal at that age. Six-layered, as well as five-layered, follicles first appeared at 17 days. Between 18 and 20 days, the numbers of both medium and larger follicles increased rapidly while the number with only three layers of cells declined. The mean diameter of follicles with six or more layers increased appreciably up to Day 19, mainly due to the development of large antral 
TABLE 1

MEAN NUMBERS OF FOLLICLES WITH THREE OR MORE LAYERS AND WITH ONLY

THREE LAYERS AT EACH MOUSE AGE

\begin{tabular}{c|c|c}
\hline $\begin{array}{c}\text { Mouse age } \\
\text { (days) }\end{array}$ & $\begin{array}{c}\text { No. of follicles } \\
\text { with three or more } \\
\text { layers }( \pm S . E .)\end{array}$ & $\begin{array}{c}\text { No. of follicles } \\
\text { with three layers } \\
( \pm S . E .)\end{array}$ \\
\hline 15 & $8 \cdot 5 \pm 3 \cdot 0$ & $6 \cdot 5 \pm 2 \cdot 6$ \\
16 & $17 \cdot 0 \pm 4 \cdot 1$ & $15 \cdot 0 \pm 2 \cdot 9$ \\
17 & $35 \cdot 0 \pm 15 \cdot 2$ & $21 \cdot 8 \pm 7 \cdot 9$ \\
18 & $67 \cdot 0 \pm 2 \cdot 8$ & $45 \cdot 0 \pm 7 \cdot 1$ \\
19 & $65 \cdot 0 \pm 11 \cdot 3$ & $22 \cdot 0 \pm 4 \cdot 2$ \\
20 & $66 \cdot 0 \pm 6 \cdot 2$ & $22 \cdot 5 \pm 4 \cdot 8$ \\
\hline
\end{tabular}

Size distribution of follicles with four or more loyers $(\mu \mathrm{m})$

to $\frac{124}{143}$ to $\begin{aligned} & 144 \\ & 166\end{aligned}$ to $\frac{167}{189}$ to $\frac{190}{212}$ to $_{235}^{213} 2$ to $\begin{aligned} & 236 \\ & 259\end{aligned}$ to $\begin{aligned} & 260 \\ & 282\end{aligned}>282$

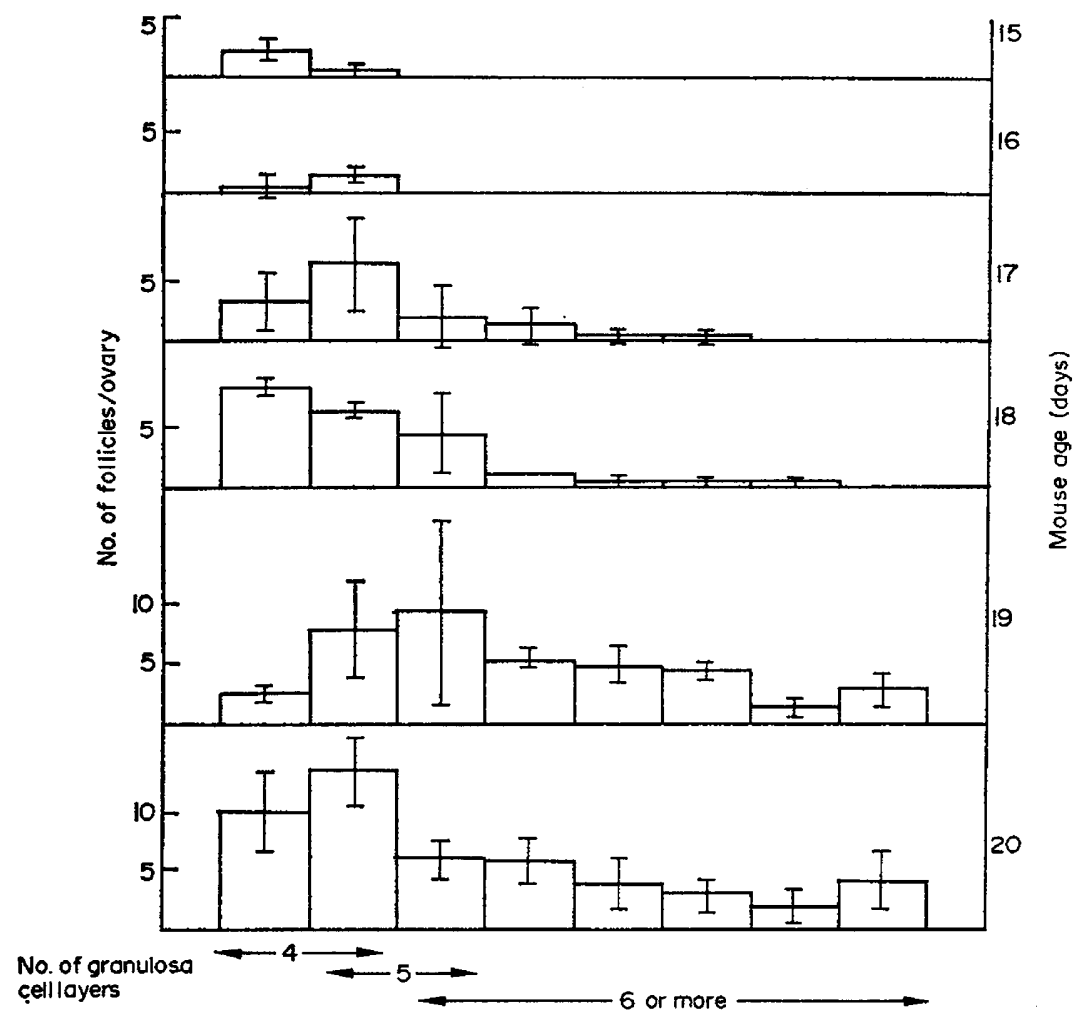

TExT-Fig. 1. Mean numbers of follicles with four or more layers in various diameter classes. Vertical bars show the S.E. 
cavities. By that time, most of the ovarian tissue consisted of large antral follicles, many of which showed signs of atresia.

One follicle containing a small antral space was observed at 16 days. Larger spaces were present in the increasing numbers of bigger follicles from Day 17 to Day 19 but Graafian follicles were only present on Day 20. The theca developed from one or two layers of flattened cells on Day 16 to three or four layers around the larger follicles by Day 20. Little interstitial tissue was seen at any age and it was often highly eosinophilic.

The results indicate two phases of ovarian development during the brief period investigated. Up to Day 18, recruitment into the population of follicles with three or more layers of granulosa cells took place; thereafter, it stopped. From Day 17, onwards, rapid growth occurred within this population. The exceptional variability on Day 17 may have arisen from imperfect synchronization of mice passing from one phase to the other.

Growth of one- and two-layered follicles, as well as of larger ones, is stimulated in vitro by FSH, while LH has been shown to stimulate preferentially the growth of follicles with three or more layers of granulosa cells (Ryle, 1972). This suggests that, up to Day 17, FSH predominated in the control of follicle growth but that thereafter LH was exerting a greater influence. Weisz \& Ferin (1970) reported that, in rats, the serum concentration of $\mathrm{LH}$ rose to a maximum at 14 days, a time at which pituitary LH concentrations were also rising. Differences between individual animals in serum LH concentrations were considerable at both 14 and 18 days. An increased release of $\mathbf{L H}$ in the mouse at 17 days might also have halted the recruitment from follicles with fewer than three layers of granulosa cells since relatively high concentrations of this hormone appear to inhibit the growth of such follicles in vitro (J. A. Boggis and M. Ryle, in preparation). Alternatively, since sufficiently high concentrations of various steroids inhibit follicle growth in vitro (J. Kent, in preparation) the larger follicles, stimulated by $\mathbf{L H}$, may have released enough steroid to cause selective inhibition of smaller ones.

This work was supported by grants from Abbott Laboratories Ltd and the Ford Foundation.

\section{REFERENCES}

BarRaclough, C. A. (1955) Influence of age on response of preweaning female mice to testosterone propionate. Am. F. Anat. 97, 493.

BEN-Or, S. (1963) Morphological and functional development of the ovary of the mouse. I. Morphology and histochemistry of the developing ovary in normal conditions and after FsH treatment. $\mathcal{J}$. Embryol. exp. Morph. 11, 1.

BRAmbell, F. W. R. (1927) The development and morphology of the gonads of the mouse. I. The morphogenesis of the indifferent gonad and the ovary. Proc. R. Soc. B, 101, 391.

Byskov, A. G., Pedersen, T. \& Peters, H. (1970) Development of the stroma in the immature mouse ovary. In: Gonadotrophins and Ovarian Development, p. 228. Eds. W. R. Butt, A. C. Crooke and M. Ryle. Livingstone, Edinburgh and London.

ENGLE, E. T. (1931) Prepubertal growth of the ovarian follicle in the albino mouse. Anat. Rec. 48, 341. Pedersen, T. (1969) Follicle growth in the immature mouse ovary. Acta endocr., Copenh. 62, 117.

Pedersen, T. (1970) Determination of follicle growth rate in the ovary of the immature mouse. $\mathcal{F}$. Reprod. Fert. 21, 81. 
Pedersen, T. \& Peters, H. (1968) Proposal for a classification of oocytes and follicles in the mouse ovary. 7. Reprod. Fert. 17, 555.

Peters, H. (1969) The development of the mouse ovary from birth to maturity. Acta endocr., Copenh. 62, 98.

Ryle, M. (1971) The time factor in responses to pituitary gonadotrophins by mouse ovaries in vitro. $\mathcal{F}$. Reprod. Fert. 25, 61.

RYLE, M. (1972) The growth in vitro of mouse ovarian follicles of different sizes in response to purified gonadotrophins. F. Reprod. Fert. 30, 395.

Stegner, H-E. \& ONKen, M. (1971) Follikelbildung und Entwicklung der Zwischenzellen im Ovar der infantilen Maus. Cytobiologie, 3, 240.

Weisz, J. \& Ferin, M. (1970) Pituitary gonadotrophins and circulating LH in immature rats. A comparison between normal females and males and females treated with testosterone in neonatal life. In: Gonadotrophins and Ovarian Development, p. 339. Eds. W. R. Butt, A. C. Crooke and M. Ryle. Livingstone, Edinburgh and London. 